\title{
Seasonal changes in optical properties of two contrasting tropical freshwater systems
}

\author{
Luciana P.M. BRANDÃO, ${ }^{1,2 *}$ Peter A. STAEHR, ${ }^{1}$ José F. BEZERRA-NETO ${ }^{2}$
}

${ }^{1}$ Department of Bioscience, Aarhus University, Frederiksborgvej 399, DK-4000 Roskilde, Denmark; ${ }^{2}$ Limnea, ICB, Federal University of Minas Gerais, Av. Antonio Carlos 6627, Pampulha, Belo Horizonte, Minas Gerais, Brazil

*Corresponding author: lucianapmb@hotmail.com

\begin{abstract}
We investigated how allochthonous and autochthonous sources of dissolved organic matter (DOM) affected the optical conditions and chemical characteristics of two contrasting tropical freshwater systems (Dom Helvécio-DH and Pampulha Reservoir) in a dry and rainy period in 2013. We analyzed PAR (photosynthetically active radiation) and UV (ultraviolet) attenuation coefficients, nutrients, chlorophylla (Chl-a), dissolved organic matter (DOC) and spectral characteristics of CDOM (colored dissolved organic matter). Significant differences in CDOM sources and quantity were observed, with a dominantly terrestrial input in DH during the rainy period with approximately $50 \%$ higher DOC and Chl-a levels, and a doubling in total nitrogen (TN) and total phosphorus (TP) compared to the dry winter period. The eutrophic Pampulha had several fold higher levels of DOC, Chl-a, TN and TP, with organic matter of mostly originating from phytoplankton in both seasons. Differences in source and quantity had strong implications on water transparency, DOC concentrations, CDOM quality and its susceptibility to photo- and biodegradation. DH was several fold clearer in both the UV and PAR spectrum. In DH transparency to both UV and PAR radiation was highest during the summer, suggesting elevated photo- and biodegradation during stratification. Pampulha was most transparent in the dry period even during period of algal bloom. In both systems we observed seasonal variations in concentrations of nutrients and Chl-a, and in DH differences were also found in DOC concentrations as well as the specific UV absorbance (SUVA 254$)$ and molecular size (M). Our results documents that different sources of DOM and seasonal inputs reflect in the seasonality of apparent and inherent optical properties and nutrients availability with implications for water quality and aquatic community.
\end{abstract}

Key words: CDOM; DOM; optical properties; photodegradation; carbon source.

Received: October 2015. Accepted: April 2016.

\section{INTRODUCTION}

The dissolved form of organic matter (DOM) constitutes about $90 \%$ of the total pool of organic matter (Tranvik and Wachenfeldt, 2009), and understanding of the production and transformation of DOM is of key importance in studies of carbon cycling in lakes (Thurman, 1985; Bertilson and Tranvik, 2000). DOM represents a complex of compounds and derives from main sources: allochthonous material produced from degradation of humic substances coming from runoff of terrestrial origin (Kieber et al., 2006; Miller et al., 2009); and autochthonous material, produced by autotrophic and heterotrophic in situ activities, but mainly by the bacterial degradation of phytoplankton and macrophytes (Kritzberg et al., 2004; Hanamachi et al., 2008; Henderson et al., 2008; Guillenette and Del Giorgio, 2012). The two different sources of DOM can be distinguished from differences in their optical and chemical characteristics. The DOM from autochthonous source is furthermore more biologically labile than the DOM from allochthonous origin, which absorbs more solar radiation, has higher molecular weight due to the more complex aromatic molecules in its composition (McKnight et al., 1994; Benner, 2002).
CDOM is the chromophoric or colored part of the DOM and also an optically active component which plays an important role in freshwater systems. CDOM absorbs solar radiation reducing exponentially the penetration of light in the water column and the absorption increases from long to short wavelengths being higher in the ultraviolet (UV) range (Twardowski et al., 2004). The CDOM absorption is due to photo-oxidation (known as photodegradation) of the molecules that can originate photo products or can be completely mineralized to $\mathrm{CO}_{2}$, affecting the amount of $\mathrm{CO}_{2}$ emission to the atmosphere (Arrigo et al., 2011). This phenomenon restricts the available light for production, abundance and distribution of pelagic and benthic primary producers, with consequences for higher trophic levels in the ecosystem (McMahon et al., 1992; Gallegos and Moore 2000). Moreover, it significantly reduces harmful effects of UV radiation on aquatic organisms (Zhang et al., 2011b). Several studies in temperate aquatic systems have demonstrated the role of CDOM in the light attenuation (Christian and Sheng, 2003; Balogh et al., 2009; Yamaguchi et al., 2013), but the effect of CDOM in tropical systems still requires effort (Obrador and Pretus, 2008) especially in lakes. DOM is furthermore an energy source for the bacterial pro- 
duction, which is responsible for the regeneration of nutrients in the water (Lønborg et al., 2010). It also operates in the physical, chemical and biological processes of transport and availability of nutrients and the development of blooms of phytoplankton in eutrophic lakes (Qualls and Richardson, 2003; Coble, 2007; Stedmon et al., 2007) and it is an important component to estimates and effective management of water quality and eutrophication control (Zhang et al., 2011a). Understanding the environmental conditions and physical, chemical and biological processes involved in the production and mineralization of DOM, is therefore also of great importance to assess the role of lakes in carbon cycling at regional and global scale (Bertilsson and Tranvik, 2000; Johannessen et al., 2007). Although the importance of distribution and cycling of DOM is well known, the origins, transport and transformations are not well understood (Zhang et al., 2009), especially in tropical environments.

The composition and concentration of DOM in aquatic ecosystems depends mainly on the spatial and seasonal variability of its sources and the availability of nutrients and radiation, which also affects the rates of photo- and microbial degradation (biodegradation) of these compounds (Bracchini et al., 2009; Zhang et al., 2011a). The spatial variation is given by the heterogeneity of the environment, as the presence or absence of macrophytes, different depths and the proximity to the borders which increases the impact by the input of allochthonous matter and nutrients by runoff (Wetzel, 1992; Tao, 1998; Obrador and Pretus, 2013). The seasonal variation derives from changes in DOM sources, such as higher input of allochthonous organic matter in the lake during the rainy season and the highest incidence of radiation in spring and summer, which can increase photodegradation rates of CDOM and still favor the lability of the molecules through the breakage part, facilitating microbial degradation (Bertilsson and Tranvik, 1998; Neale et al., 2007; Fasching and Battin, 2012; Catalán et al., 2013). Furthermore, CDOM degradation is also affected by the availability of nutrients throughout the year, a limiting factor for microbial degradation. In eutrophic lakes, degradation of phytoplankton is an important source of CDOM and regeneration of nutrients for bacteria and also the phytoplankton community, especially after seasonal blooms of these organisms (Bracchini et al., 2009; Zhang et al., 2009, 2013b).

The CDOM spectrophotometry and fluorescence spectroscopy are important tools in studies of composition and origin of organic matter (Helms et al., 2008). There are currently some metrics extracted from the CDOM absorbance spectrum that provide information about the chemical characteristics and quality of its composition. The increase of the specific UV absorbance ( $\mathrm{SUVA}_{254}$; $\mathrm{mg}$ $\mathrm{C} \mathrm{L}^{-1} \mathrm{~m}^{-1}$ ) indicates an increase of compounds of higher aromaticity (Weishaar et al., 2003). The spectral slope $\mathrm{S}_{275-295}\left(\mathrm{~nm}^{-1}\right)$ indicates different sources of CDOM and changes related to photodegradation and molecular size, while $\mathrm{S}_{350-400}\left(\mathrm{~nm}^{-1}\right)$ indicates changes in CDOM related to biodegradation (Helms et al., 2008). $\mathrm{S}_{\mathrm{R}}$ is a ratio between both spectral slopes $\left(\mathrm{S}_{275-295}: \mathrm{S}_{350-400}\right)$ and indicates the relationship between photodegradation and biodegradation of CDOM (Helms et al., 2008). The estimated apparent molecular size (M) is obtained by the ratio of two absorption coefficients (a250:a365), based on the fact that declining ratio indicates increasing of molecular size (De Haan, 1987; Peuravuori and Pihlaja, 1997). In recent decades researchers have used these spectral metrics to investigate the optical properties in temperate aquatic systems (Zhang et al., 2007a, 2007b, 2009; Helms et al., 2008; Bracchini et al., 2010), but studies using this approach in tropical environments are still scarce and little is known to Brazilian aquatic systems (Teixeira et al., 2011, 2013; Bittar et al., 2015).

The aim of the study was to investigate the effects of CDOM sources on the light environment and nutrient availability in the two contrasting tropical freshwater systems. Specifically we focus on DOM properties obtained from the CDOM spectral absorbance (absorbance coefficient $\left(\mathrm{a}_{350}\right)$, spectral slopes $\left(\mathrm{S}_{275-295}, \mathrm{~S}_{350-400}\right)$, slope ratio $\left(\mathrm{S}_{\mathrm{R}}\right)$, molecular size (M)). Dom Helvécio-DH (Middle Rio Doce, MG, Brazil) is a warm monomictic, deep $(\max 39.5 \mathrm{~m})$, dendritic, oligotrophic and natural lake located in a natural Atlantic forest. The input of DOM and nutrients to DH occurs via runoff during the rainy season, when the environment is thermally stratified (Petrucio et al., 2005). However, most of the DOM remains below the thermocline due to temperature differences (Reynolds, 2009) and becomes dispersed into the entire water column during the mixing of water in the dry season, increasing the DOC and CDOM concentrations in surface waters (Brighenti et al., 2015). In contrast, Pampulha (Belo Horizonte, MG, Brazil) is a shallower $(\max 17 \mathrm{~m})$ and less dendritic eutrophic reservoir with reoccurring phytoplankton blooms throughout the year, especially in the summers during thermal stratification. As in other eutrophic lakes, concentrations and quality of the DOM are strongly influenced by the high phytoplankton abundance (Tôrres et al., 1998; Bracchini et al., 2009; Zhang et al., 2009, 2013b). Considering that the main source of dissolved organic matter in the eutrophic Pampulha reservoir comes from degradation of phytoplankton, especially after an algal bloom, while the main source of DOM in DH Lake comes from allochthonous material from the forest in rainy season, we hypothesized that: a) The different sources of DOM (allochthonous in DH and autochthonous in Pampulha) provide different optical qualities of CDOM, which alters the under-water light climate and the availability of nutrients; b) The lakes have seasonal differences in their inherent and apparent optical properties. The autochthonous organic matter in the Pampulha reservoir is expected to increase with the increase of phytoplankton abundance during higher availability of nutrients, which 
will reduce the attenuation of visible and ultraviolet radiation by algae and CDOM absorption and also light dispersion by the phytoplankton community. In opposition to this we expect that DH Lake will show higher water transparency during the rainy season because of intense photobleaching in the epilimnion, and because most of the organic matter coming from the catchment remains in the hypolimnion until the mixing in winter.

\section{METHODS}

\section{Study area}

Lake Dom Helvécio (DH) is located inside the Rio Doce State Park - PERD (Middle Rio Doce, MG, Brazil). The lake complex in the Middle Rio Doce is one of the most important districts of lakes in Brazil, with approximately 130 lakes, 42 of them located inside the PERD area, which is the largest remnant of the Atlantic Forest in Minas Gerais, totaling 36,000 ha (Maia-Barbosa et al., 2010) (Fig. 1a). This lake is one of the deepest natural lakes in Brazil (maximum depth: $39.5 \mathrm{~m}$ ), surrounded by Atlantic forest. It is oligotrophic [total phosphorus: 3.0$22.0 \mu \mathrm{g} \mathrm{L}^{-1}$, annual mean $11.2 \mu \mathrm{g} \mathrm{L}^{-1}$; Chlorophyll-a (Chl- a): $0.5-11.0 \mu \mathrm{g} \mathrm{L}^{-1}$, annual mean $4.5 \mu \mathrm{g} \mathrm{L}^{-1}$, has a perimeter of $37.7 \mathrm{~km}$, area equal to $5.27 \times 10^{6} \mathrm{~m}^{2}$ and volume equal to $5.94 \times 10^{7} \mathrm{~m}^{3}$ (Bezerra-Neto and Pinto-Coelho, 2008). $\mathrm{DH}$ is a warm monomictic lake, with a stable thermal stratification period beginning in September and lasting until May (rainy period) and a mixed period from June to August (dry period) (Barbosa and Tundisi, 1980; Henry and Barbosa, 1989; Briguenti et al., 2015).

The Pampulha reservoir was inaugurated in 1938 and rebuilt in 1957 following a dam rupture, and is together with its architectural set an important tourist area in the metropolitan region of Belo Horizonte, Minas Gerais, Brazil. This reservoir is eutrophic (total phosphorus: 135$819 \mu \mathrm{g} \mathrm{L}^{-1}$, annual mean $6500 \mu \mathrm{g} \mathrm{L}^{-1}$; Chl-a: 10-315 $\mu \mathrm{g}$ $\mathrm{L}^{-1}$, annual mean $75 \mu \mathrm{g} \mathrm{L}^{-1}$ ), has an original perimeter of $21 \mathrm{~km}$, maximum depth of $17 \mathrm{~m}$, and receives domestic and industrial sewage and other pollutants that contribute to poor water quality and exacerbate eutrophication (Champs, 1992; Novais, 1992, Pinto-Coelho, 1998, Resck et al., 2007) (Fig. 1b). Pampulha remains thermally stratified between September and April (rainy period) and the mixing water begins in May until August (dry period) (Figueredo and Giani, 2001; Pinto-Coelho et al., 2003).

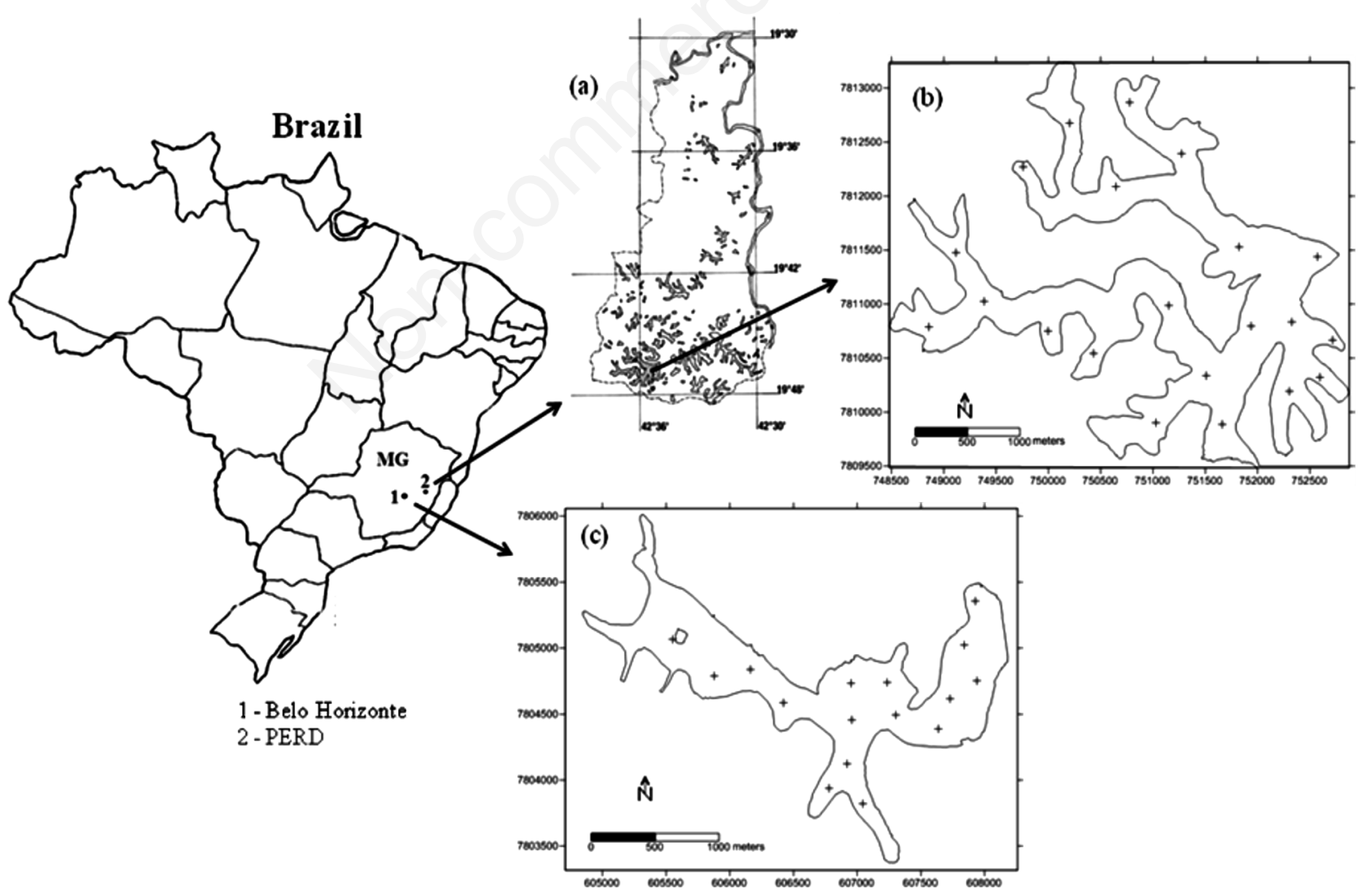

Fig. 1. Location at (a) Rio Doce State Park (PERD) and (b) Dom Helvécio Lake, and (c) Pampulha Reservoir in Belo Horizonte, Minas Gerais (MG), Brazil. 


\section{Field measurements and laboratory analysis}

The sampling was carried out in January (rainy summer) and August (dry winter) 2013 in 21 sampling stations in DH Lake and in March (rainy autumn) and July (dry winter, during a bloom of cyanobacteria) 2013 in 16 sampling stations in Pampulha reservoir (Fig. 1 a,b).

For characterization of the systems vertical profiles of water column temperature $\left({ }^{\circ} \mathrm{C}\right)$ at the central point were measured every meter from surface to the bottom using a probe Hydrolab DS5 (Hach Inc., Loveland, CO, USA).

Vertical profiles of photosynthetically active radiation (PAR) and ultraviolet radiation (UV) (between 10:00 and 14:00) were performed using a radiometer BIC (Biospherical Instruments) in each site sampling. The profiles were made on the sun side of the boat avoiding shadows and measurements during days with great clouds were avoided. The radiometer was attached to a battery and notebook with the software LoggerLight TM (Biospherical Intruments, San Diego, CA, USA) while collecting radiation data PAR and UV (305, $340 \mathrm{~nm})$ and depth during descent and ascent up of the probe. Water samples $(0.5 \mathrm{~m}$ from the surface) were collected using a van Dorn bottle (5L). These samples were filtered immediately after sampling for Chl-a (0.47 $\mu \mathrm{m}$ filter) and TSM (AP040 filter) and the filters were frozen until analysis. Water samples were also filtered for analysis of dissolved organic carbon (DOC) and colored dissolved organic matter (CDOM) $(0.22 \mu \mathrm{m}$ Millipore filter) and stored in amber glass bottles (pre-washed with distilled water and hydrochloric acid $10 \%$ ) at $4^{\circ} \mathrm{C}$ in the dark. The chlorophyll-a concentration corrected by pheophytin (Chl-a) was obtained by acetone extraction $(90 \%)$ measured in a spectrophotometer (UV-VIS, Shimadzu Inc., Columbia, MD, USA) at 665 and $750 \mathrm{~nm}$ and calculated according to APHA (1998). The DOC concentration $\left(\mathrm{mg} \mathrm{L}^{-1}\right)$ was obtained by catalytic oxidation method of high temperature using TOC Analyzer (Shimadzu TOC-5000). Total suspended solids (TSM) were determined by the gravimetric method, considering the difference between the dry weight of AP40 Millipore filters $\left(105^{\circ} \mathrm{C}\right.$ for $\left.2 \mathrm{~h}\right)$ before and after the filtration of water samples (APHA, 1998).

Unfiltered water samples were taken for analysis of total nitrogen - TN (TOC Analyzer, Shimadzu TOC-5000) and total phosphorus - TP (according to Mackereth et al., 1978).

\section{Calculation of the optical properties}

The diffuse PAR and UV attenuation coefficients $\left(\mathrm{K}_{\mathrm{d}(\mathrm{PAR})}\right.$ and $\left.\mathrm{K}_{\mathrm{d}(\mathrm{UV})}\right)$ were calculated as the linear slope between depth and the natural logarithm of the measured radiation.Absorption spectra were obtained between $250 \mathrm{~nm}$ and $700 \mathrm{~nm}$ at $1 \mathrm{~nm}$ intervals in a spectrophotometer (UVVIS Shimadzu) using $5 \mathrm{~cm}$ quartz cuvette and Milli-Q water as a reference. The absorption spectra of each sam- ple was performed in triplicate and determined using the Spectrum Pack Program software (Shimadzu Inc.). The absorption coefficients ( $a \lambda)$ were derived from absorbance measurements $(A \lambda)$ according to the equation $\mathrm{a}(\lambda) \mathrm{m}^{-}$ $1=2,303 \mathrm{~A}(\lambda) \mathrm{L}^{-1}$, where $\mathrm{L}$ is the optical path of the cuvette (in meters). Absorption coefficients were corrected for backscattering by subtracting the value of the coefficient at $700 \mathrm{~nm}$. The spectrophotometric absorption coefficient at $350 \mathrm{~nm}\left(\mathrm{~m}^{-1}\right)$ was used as an index of CDOM concentration (Zhang et al., 2011a).

The spectral slope $\mathrm{S}\left(\mathrm{nm}^{-1}\right)$ was calculated for wavelengths between 275-295 $\mathrm{nm}$ and 350-400 nm (Helms et al., 2008) and it was estimated using linear adjustment technique between log values of the absorption coefficients and the specific wavelength range. The slope ratio $\left(\mathrm{S}_{\mathrm{R}}\right)$ was obtained by the equation $\mathrm{S}_{\mathrm{R}}=\mathrm{S}_{275-295 \mathrm{~nm}} / \mathrm{S}_{350-400 \mathrm{~nm}}$, where $S$ is the spectral slope. The estimated apparent molecular size (M) was obtained by the ratio of the absorption coefficients at 250 and $365 \mathrm{~nm}$ (a250/ a365) (De Haan, 1987; Peuravuori and Pihlaja, 1997). The specific UV absorbance $\left(\mathrm{SUVA}_{254}\right)\left(\mathrm{mg} \mathrm{C} \mathrm{L}^{-1} \mathrm{~m}^{-1}\right)$ was calculated dividing the value of the absorption coefficient at $254 \mathrm{~nm}$ by the concentration of DOC $\left(\mathrm{mg} \mathrm{L}^{-1}\right)$ (Weishaar et al., 2003).

\section{Statistical analysis}

Differences in parameters between seasons were assessed by independent sample $t$-test (for parametric data) and Mann-Whitney (for non parametric data) (significant $\mathrm{P}<0.05$ ), and differences between freshwater systems were assessed with Two-way Analysis of Variance (significant $\mathrm{P}<0.05$ ). Pearson correlations were made to examine the relationships between all the parameters measured (significant $\mathrm{P}<0.05$ ).

\section{RESULTS}

\section{Differences between the two contrasting freshwater systems}

The hyper eutrophic Pampulha reservoir had significantly higher concentrations of nutrients (21 times higher for TN and 28 for TP), Chl-a (5.8 times) and DOC (1.4 times) compared to the oligotrophic DH Lake. As Pampulha also had higher $\mathrm{CDOM}_{350}$ absorbance (3.3 fold higher), both PAR and UV attenuation was significantly higher than in DH. Indices of CDOM quality or composition furthermore indicated DOM of different origin as Pampulha had DOC of higher specific UV absorbance $\left(\mathrm{SUVA}_{254}\right)$, smaller spectral slopes $\left(\mathrm{S}_{275-295}, \mathrm{~S}_{350-400}\right)$, lower spectral slope ratio $\left(S_{R}\right)$ and higher molecular size of CDOM (lower M) than DH (Tabs. 1 and 2, Figs. 2 a-d and 3 a-d). CDOM absorption was generally higher over the entire spectrum in Pampulha, especially in the UV range (Fig. 4 a,b). 


\section{Seasonality in optical properties}

Concentration of nutrients, Chl-a and DOC were significantly higher in the fully mixed dry season in DH (Fig. 2 a-d). The PAR, UV-A and UV-B attenuation were also higher during dry period (Fig. 5a). In this lake, only $\mathrm{SUVA}_{254}$ and $\mathrm{M}$ values (Fig. 3a) were higher in rainy period. In Pampulha we found that concentrations of TP (Fig. 2b), PAR and UV attenuation (Fig. 5b) were significantly higher during the rainy season. Only Chl-a and TN concentrations were higher in dry period (Fig. 2d) in this reservoir (Tabs.1 and 2).

Analysing the CDOM absorption spectrum at 21 points in $\mathrm{DH}$ and at 16 in Pampulha, during a rainy and a dry period we noticed that the spatial variation in each environment was smaller during the rainy period compared with the dry period. For DH, the mean absorption spectrum (black line in Fig. 4a) was higher in the dry period for absorption at wavelengths shorter than $350 \mathrm{~nm}$. For Pampulha the mean absorption (black line in Fig. 4b) was equal in both seasons.
Significant and positive Pearson correlation was observed to $\mathrm{DH}$ between $\mathrm{S}_{350-400}$ and nutrients concentrations (TN; $\mathrm{r}=0.52, \mathrm{P}<0.015 ; \mathrm{TP} ; \mathrm{r}=0.82, \mathrm{P}<0.000$ ) only for rainy period data, which indicates that biodegradation might be limited by nutrients in this time. In the Pampulha reservoir, we found significant Pearson correlations between $\mathrm{CDOM}_{350}$ and Chl-a in the dry period $(\mathrm{r}=0.88$, $\mathrm{P}<0.000$ ), when there was an algal bloom. The $\mathrm{CDOM}_{350}$ was also positively correlated with the coefficients of attenuation of PAR only in the dry period $\left(\mathrm{K}_{\mathrm{d}(\mathrm{PAR})} ; \mathrm{r}=0.80\right.$, $\mathrm{P}<0.000$ ) and with $\mathrm{UV}$ radiation in both periods (dry period: $\mathrm{K}_{\mathrm{d}(305)} ; \mathrm{r}=0.81, \mathrm{P}<0.000 ; \mathrm{K}_{\mathrm{d}(340)} ; \mathrm{r}=0.90, \mathrm{P}<0.000$; rainy period: $\mathrm{K}_{\mathrm{d}(305)} ; \mathrm{r}=0.52, \mathrm{P}=0.037 ; \mathrm{K}_{\mathrm{d}(340)} ; \mathrm{r}=0.76$, $\mathrm{P}<0.000$ ). In addition, the TSM was positively correlated with Chl-a only in the dry period $(r=0.91, \mathrm{P}<0.000)$.

\section{DISCUSSION}

\section{Sources of DOM and underwater light climate}

The large difference between the quantity and quality

Tab. 1. Summary of parameters measured during spatial-seasonal analyses in Dom Helvécio Lake and Pampulha Reservoir, MG, Brazil.

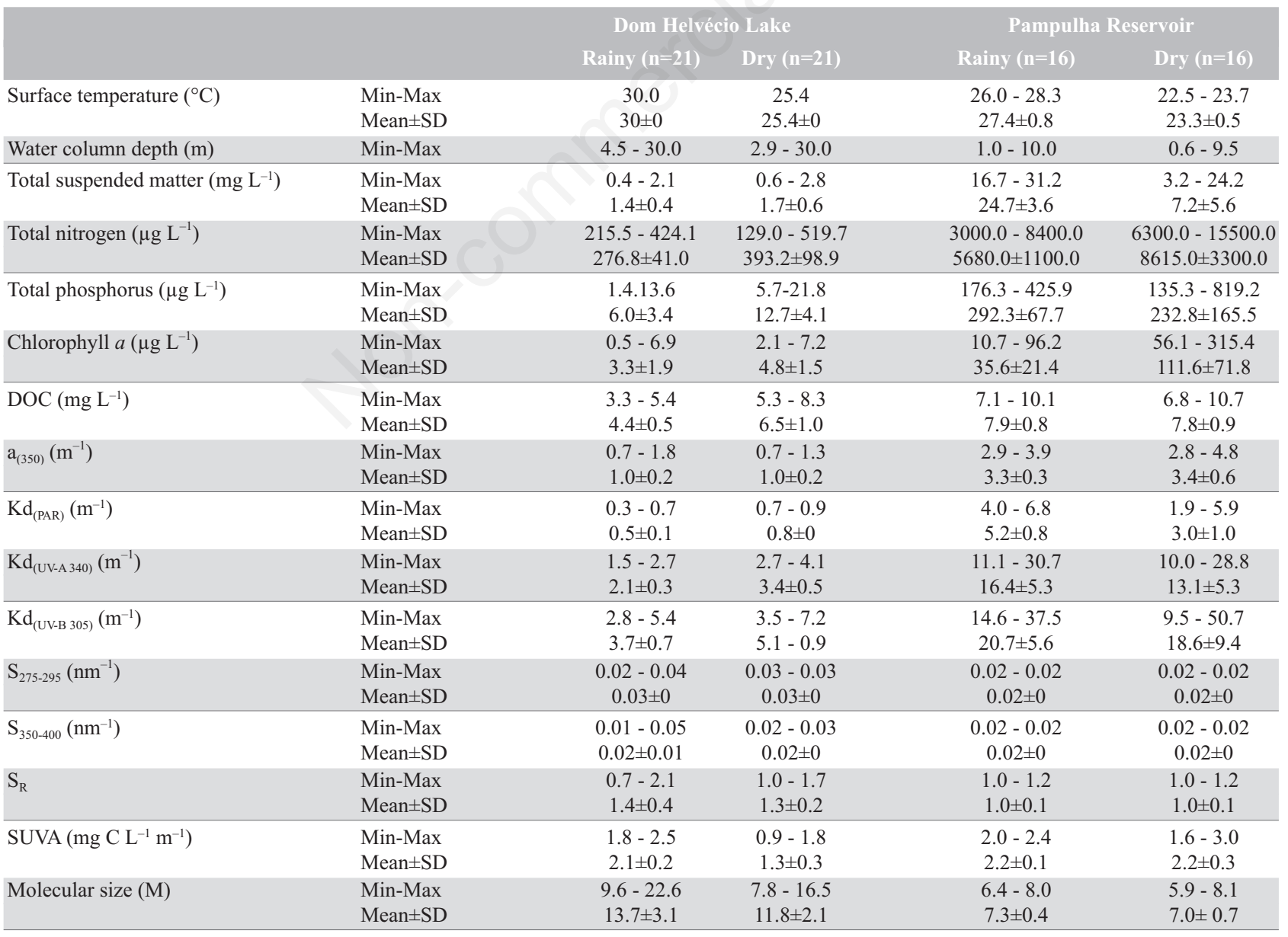

n, number of sampling stations. 
of DOM in the two studied freshwater systems indicated a terrestrial input of organic matter in DH Lake occurring mostly during the rainy period in the summer, compared to a strong autochthonous phytoplankton contribution in Pampulha reservoir related to an algal bloom especially evident in the dryer winter period.

The differences in the $\mathrm{S}_{275-295}$ values between the systems suggest that DOM originated from different sources (Helms et al., 2008). The increase of aromatic DOC (higher SUVA) during rainy period in DH strongly suggests an allochthonous source of DOM from the forested catchment around DH primarily entering the lake during this time. In Pampulha, increases in CDOM absorbance was positively correlated with increasing of Chl-a during an algal bloom in dry winter indicating an autochthonous input of DOM. Other studies have linked DOM source from phytoplankton degradation considering the positive correlations between CDOM absorption and Chl-a (Kahru and Mitchell, 2001; Rochelle-Newall and Fisher, 2002; Zhang et al., 2013b).

The DOM source affects some characteristics of lakes, as their transparency to UV and PAR radiation, and recently some studies have compared the differences in optical quality between DOM from autochthonous and allochthonous sources (Spencer et al., 2009; Bracchini et al., 2010; Shank et al., 2010; Catalán et al., 2013; Zhang et al., 2013a). The PAR and UV attenuation in Pampulha were much higher than in DH. In Pampulha we observed that the predominantly autochthonous DOM was coupled to the attenuation of PAR (positive correlation between $\mathrm{CDOM}_{350}$ and PAR attenuation coefficients only in dry period) and ultraviolet radiation (positive correlations in dry and rainy period). A similar relation was not found for the allochthonous DOM in DH, and it was already observed for this lake that PAR and UV attenuation were strongly dependent on light absorption by particulate matter (tripton and phytoplankton) while CDOM only contributed with less than $22 \%$ in total attenuation during monthly and spatial sampling in 2013. However, when the CDOM comes from phytoplankton degradation, as in eutrophic environments like Pampulha, it may greatly increase its contribution to the attenuation of radiation and CDOM absorbance (CDOM ${ }_{350}$ higher in Pampulha) during blooms (Zhang et al., 2007a). The different DOM sources in these systems also alter the importance of DOM degradation processes, as allochthonous terrestrial carbon is known to be more humic consisting of heavier and more aromatic molecules being typically more photodegraded. In contrast, the autochthonous microbial/algal derived DOM consisted as expected by simpler molecules of low molecular weight, less affected by photodegradation but more susceptible to biodegradation (McKnight et al., 1994; Benner, 2002; Catalán et al., 2013, Zhang et al., 2013b).

\section{Seasonality of optical properties between the contrasting systems}

Seasonal variations were observed for nutrients and Chl-a concentration and UV and PAR attenuation for both

Tab. 2. Results of the two-way analysis of variance comparing the seasons (rainy and dry) and the freshwater systems and results of the $t$-test and Mann-Whitney comparing the seasons within each system.

\begin{tabular}{|c|c|c|c|c|c|}
\hline & \multicolumn{3}{|c|}{$\begin{array}{l}\text { Two-way Analysis of Variance ( } \mathrm{F} \text { value) } \\
\qquad \mathrm{df}=\mathbf{1}\end{array}$} & \multicolumn{2}{|c|}{ t-test / Mann-Whitney } \\
\hline & $\begin{array}{l}\text { Systems } \\
\text { (DH x PA) }\end{array}$ & $\begin{array}{l}\text { Seasons } \\
\text { (rainy } x \text { dry) }\end{array}$ & $\begin{array}{l}\text { Seasons and } \\
\text { systems } \\
\text { interactions }\end{array}$ & DH (rainy x dry) & PA (rainy $x$ dry) \\
\hline Total nitrogen $\left(\mu \mathrm{g} \mathrm{L}^{-1}\right)$ & $425.45^{* * *}$ & $21.33 * * *$ & $18.20^{* * *}$ & $* * * 2$ & $* * 2$ \\
\hline Total phosphorus $\left(\mu \mathrm{g} \mathrm{L}^{-1}\right)$ & $169.67 * * *$ & 1.84 & 2.90 & $* * * 1$ & $* * * 2$ \\
\hline Chlorophyll $a\left(\mu \mathrm{g} \mathrm{L}^{-1}\right)$ & $10.68^{* *}$ & $5.25 *$ & $5.03 *$ & $* * 1$ & $* * * 2$ \\
\hline $\mathrm{DOC}\left(\mathrm{mg} \mathrm{L}^{-1}\right)$ & $155.63^{* * *}$ & $25.76 * * *$ & $32.83^{* * *}$ & $* * * 2$ & ns 2 \\
\hline $\mathrm{a}_{(350)}\left(\mathrm{m}^{-1}\right)$ & $887.87 * * *$ & 0.26 & 1.32 & ns 2 & ns 2 \\
\hline $\mathrm{Kd}_{(\mathrm{PAR})}\left(\mathrm{m}^{-1}\right)$ & $651.92 * * *$ & $48.44 * * *$ & $85.07 * * *$ & $* * * 1$ & $* * * 2$ \\
\hline $\mathrm{Kd}_{(\mathrm{UV}-\mathrm{A} 340)}\left(\mathrm{m}^{-1}\right)$ & $217.67 * * *$ & 1.53 & $8.26^{* *}$ & $* * * 2$ & $* * 2$ \\
\hline $\mathrm{Kd}_{\text {(UV-B 305) }}\left(\mathrm{m}^{-1}\right)$ & $163.16^{* * *}$ & 0.08 & 2.16 & $* * * 1$ & $* 2$ \\
\hline $\mathrm{S}_{275-295}\left(\mathrm{~nm}^{-1}\right)$ & $383.27 * * *$ & 1.85 & 0.11 & ns 2 & ns 1 \\
\hline $\mathrm{S}_{350-400}\left(\mathrm{~nm}^{-1}\right)$ & $9.86^{* *}$ & 0.21 & 0.07 & ns 2 & ns 1 \\
\hline $\mathrm{S}_{\mathrm{R}}$ & $28.58 * * *$ & 0.63 & 0.35 & ns 1 & ns 1 \\
\hline SUVA (mg C L $\left.{ }^{-1} \mathrm{~m}^{-1}\right)$ & $4.26^{* * *}$ & $2.55 * * *$ & $2.89 * * *$ & $* * * 1$ & ns 2 \\
\hline Molecular size (M) & $140.91 * * *$ & $5.54 *$ & 2.85 & $* * 2$ & ns 1 \\
\hline
\end{tabular}

DH, Dom Helvécio; PA, Pampulha; $* P<0.05 ; * * P<0.01 ; * * * P<0.001 ; n$ s, not significant; 1 , parametric data and t-test was used; 2 , non-parametric data and Mann-Whitney was used. 
systems and also seasonal differences only to DH Lake in relation to the DOC concentration and the quality of $\mathrm{CDOM}\left(\mathrm{SUVA}_{254}\right.$ and M). Seasonal changes in the quality and quantity of DOM in DH suggest linkages with rainfall events and water column mixing. In contrast, the reduced seasonality in Pampulha seems attributed to reoccurring algal blooms in this reservoir, which causes several events of autochthonous production of DOM throughout the year, although most prevailing during the well mixed dryer winter period.

As we expected, the water column in DH was most transparent (both PAR and UV radiation) during the rainy season when the water column was stratified and with DOM components of a more aromatic structure (higher SUVA) and more susceptible to photobleaching (Weishaar et al., 2003; Helms et al., 2008; Catalán et al., 2013; Zhang et al., 2013a). Positive correlations between $\mathrm{S}_{350-400}$ and nutrients (TP and TN) only during the rainy season suggest that microbial degradation in the epilimnion might be limited by nutrients during thermal stratification. Nutrient limitation of primary production during the rainy season in DH Lake was observed by Brighenti et al. (2015) in a two year study of lake metabolism. In agreement with this Chla concentrations were lower in the rainy period in DH. Furthermore, nutrient limitation of phytoplankton growth raises light transparency and is expected to explain elevated levels of photoinhibition during summer (Brighenti et al., 2015). While our results showed that the increase of aromatic DOM originates from surface runoff during rainy period, DOC and nutrients concentrations were lower in the epilimnion in this period, indicating that much of the newly introduced DOM remained in the hypolimnion until later mixing of the water column in the dry and cooler winter period (Reynolds, 2009), when their concentrations increased in the water surface (Barbosa and Tundisi, 1980; Petrucio and Barbosa, 2004). Corroborating with this, we
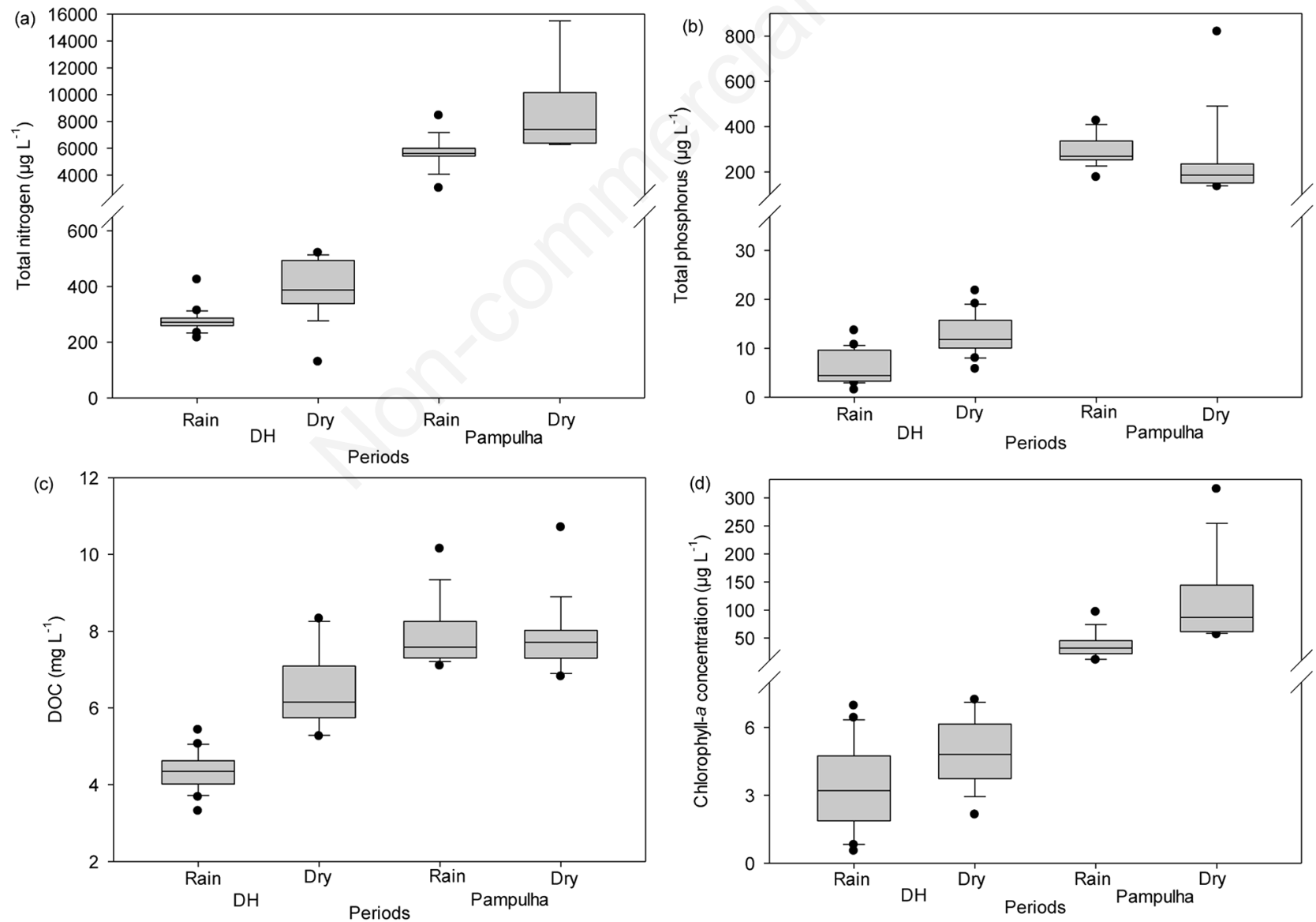

Fig. 2. Seasonal variations (center line-median, outer grey-5th/95th percentiles, bars- $95 \%$ confidence level, black circles- outlier) in the concentrations of (a) total nitrogen, (b) total phosphorus, (c) dissolved organic carbon and (d) chlorophyll- $a$ at 21 sites in Dom Helvécio Lake and 16 in Pampulha Reservoir collected in a dry and rainy period in 2013. 
observed DOM characterized by higher molecular size compounds (lower M) during the mixed winter period (Peuravuori and Pihlaja, 1997; Helms et al., 2008). Importantly, most of the sampling in DH Lake was made in areas where total depth exceeded 10 meters thus allowing a stable hypolimnion to develop over longer period of anoxia during thermal stratification from September to May. Such conditions seem favorable for the changes in DOM quality observed after full mixing of the water column. Contrary to what we expected, the Pampulha reservoir was most transparent (both UV and PAR radiation) in the dry mixing winter although it did experience a bloom of cyanobacteria. The bloom in this period can be explained by the higher concentration of nitrogen and the lower water level (approximately 1 meter), and also by the high incidence of solar radiation throughout the year. We expected that an increase of phytoplankton would increase the light attenuation coefficients $\left(\mathrm{K}_{\mathrm{d}}\right)$, especially the $\mathrm{K}_{\mathrm{d}(\mathrm{PAR})}$, but the op-

(a)
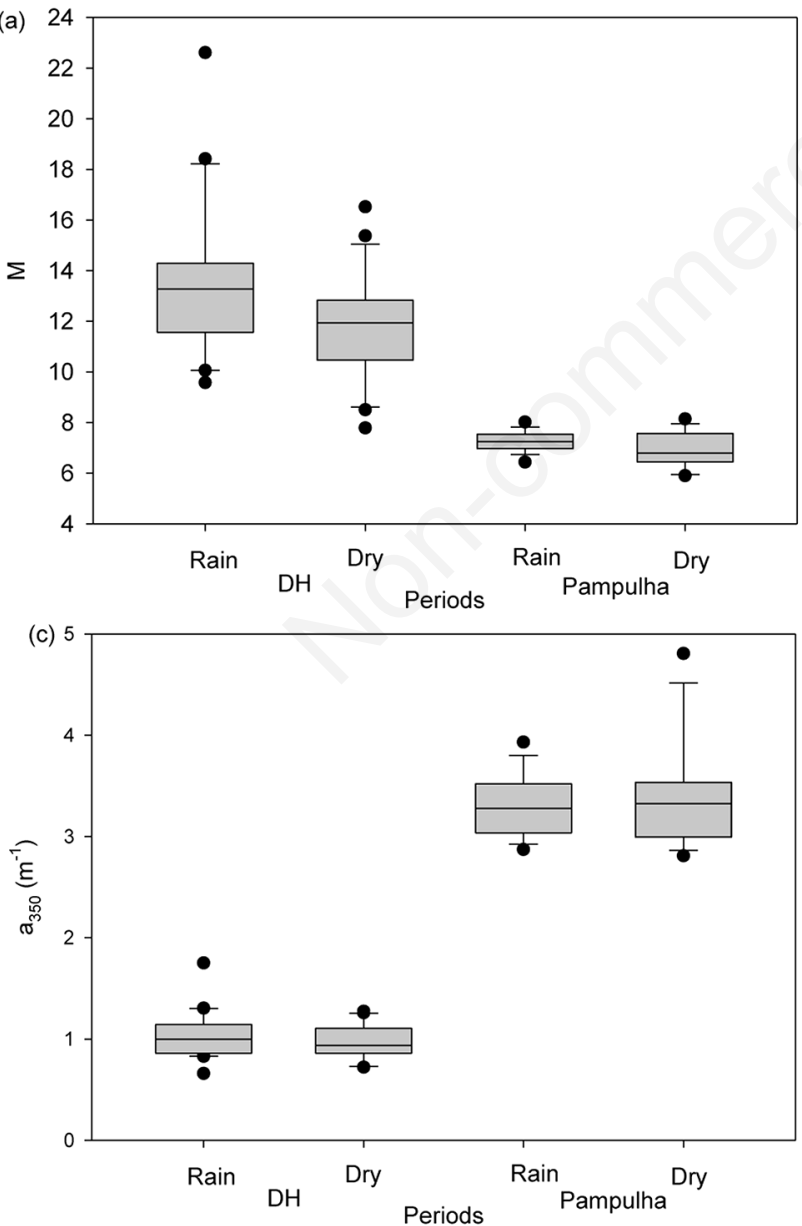

posite occurred in Pampulha. Although at high concentrations, the autochthonous carbon from phytoplankton degradation tends to be less chromophoric and attenuates radiation less, especially in the UV range (McKnight et al., 1994; Benner, 2002). The concentration of TSM during the dry-mixing period was however, lower than in the rainy season, during which TSM was uncorrelated with Chl-a and accordingly a greater amount of non-algal materials (tripton) occurred in the TSM.

In agreement with other studies it therefore seems that tripton must have accounted for most of the PAR attenuation during the rainy stratified summer (Phlips et al., 1995; Christian and Sheng, 2003; Zhang et al., 2007b).

\section{CONCLUSIONS}

As the presence of chromophoric carbon in the water protects the aquatic organisms from harmful ultraviolet
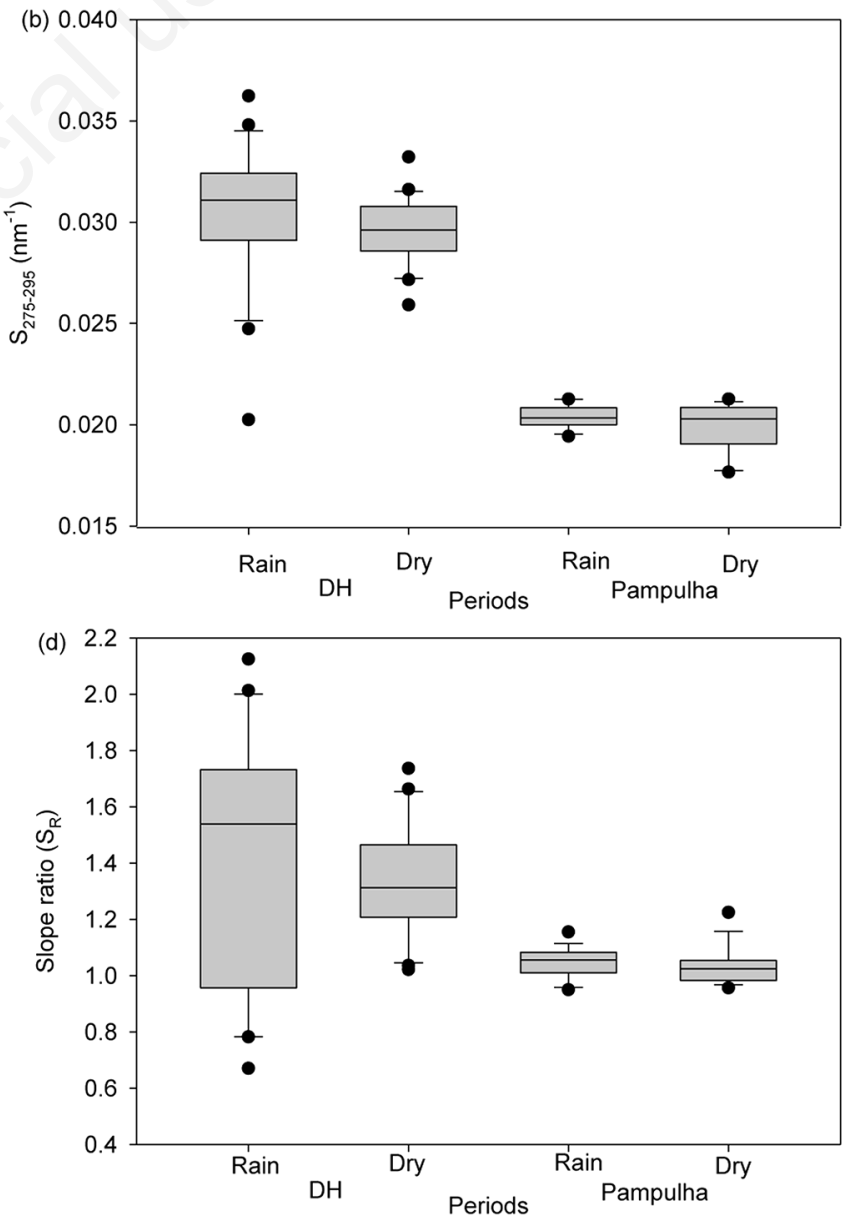

Fig. 3. Seasonal variations (center line-median, outer grey-5th/95th percentiles, bars- $95 \%$ confidence level, black circles- outlier) in (a) M, (b) spectral slope $S 2_{75-295}$, (c) absorbance of colored dissolved organic matter at $350 \mathrm{~nm}\left(\mathrm{a}_{350}\right)$ and (d) slope ratio $\mathrm{S}_{\mathrm{R}}$ at 21 sites in Dom Helvécio Lake and 16 in Pampulha Reservoir collected in a dry and rainy period in 2013. 

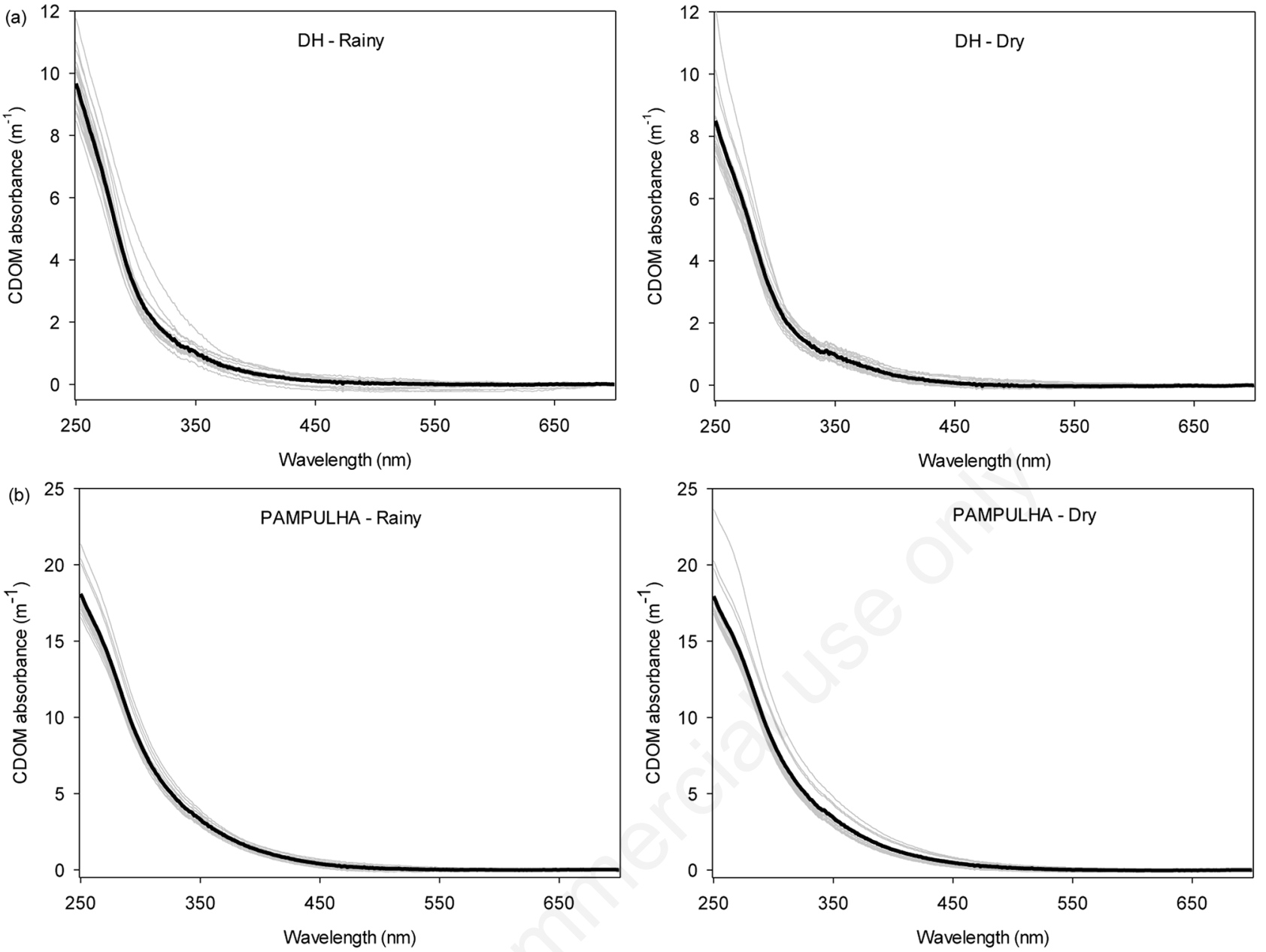

Fig. 4. Spectral absorbance curves of CDOM (a) at 21 sampling sites (grey lines) in Dom Helvécio and the mean curve (black line) and (b) at 16 sampling sites (grey lines) in Pampulha and the mean curve (black line).
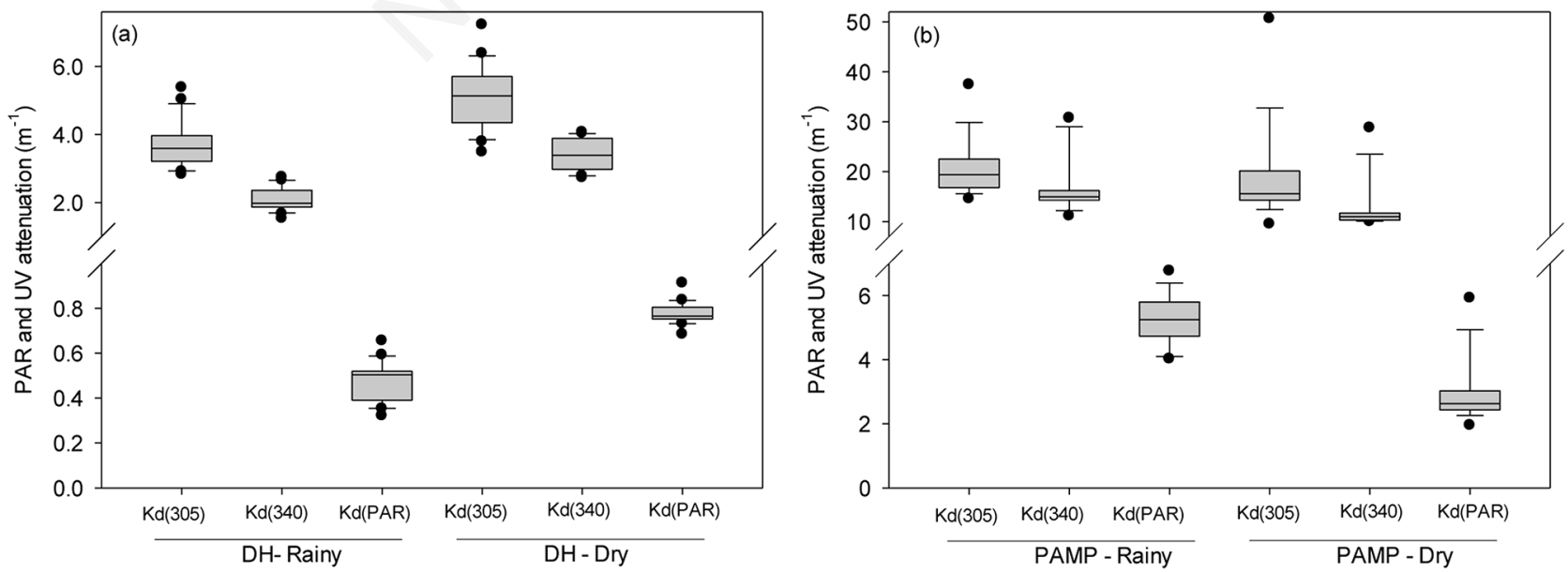

Fig. 5. Seasonal variations (center line-median, outer grey-5th/95th percentiles, bars- $95 \%$ confidence level, black circles- outlier) in the UV(305), UV (340) and PAR radiation at (a) 21 sites in Dom Helvécio Lake and (b) at 16 in Pampulha Reservoir collected in a dry and rainy period in 2013 . 
radiation and from the excessive incidence of solar radiation (Zhang et al., 2007a), our results suggest that the photoinhibition of phytoplankton primary production observed in DH during summer by Brighenti et al. (2015) is directly linked with the seasonal pattern of photobleaching of CDOM and nutrients availability, where both dependent of the sources and quality of DOM. Thereby, we demonstrated that the main source of DOM in DH come from the terrestrial input during the rainy period, reinforcing the importance of preserving the original forest surrounding the lakes to the global carbon cycle. In Pampulha reservoir we observed that degradation of phytoplankton is an important source of DOM and most likely also to the regeneration of nutrients, which has already been demonstrated for other eutrophic systems (Zhang et al., 2009, 2013, 2013b). We also found that autochthonous production of CDOM can increase the PAR and UV attenuation, as observed in the positive correlations between CDOM and attenuation coefficients only in Pampulha and during an algal bloom.

In conclusion, our results documents that tropical freshwater systems can have a clear seasonality in carbon quality and concentration related to trophic status and seasonal differences in DOM inputs, degradation and distribution in the water column. Our finding supports recent findings of a strong seasonality in primary production and organic matter decomposition in tropical lakes and has implications on our understanding of PAR and UV attenuation and water quality in such systems.

\section{ACKNOWLEDGMENTS}

We thank the Conselho Nacional de Desenvolvimento Científico e Tecnológico (CNPq) and Coordenação de Aperfeiçoamento de Pessoal de Nível Superior (CAPES) for financial support. We also thank the laboratories LIMNEA and LGAR (UFMG, Minas Gerais, Brazil) for their infrastructure and the Marcelo Costa and Patrícia Ferreira for the chemical analysis and help in this project.

\section{REFERENCES}

APHA, 1998. Standard methods for the examination of water and waste water, 22th ed. American Water Works Association.

Arrigo KR, Matrai PA, van Dijken GL, 2011. Primary productivity in the Arctic Ocean: Impacts of complex optical properties and subsurface chlorophyll maxima on large-scale estimates. J. Geophys. Res. 116:C11022.

Balogh KV, Németh B, Voros L, 2009. Specific attenuation coefficients of optically active substances and their contribution to the underwater ultraviolet and visible light climate in shallow lakes and ponds. Hydrobiologia 632:91-105.

Bannister TT, 1974. Production equations in terms of chlorophyll concentration, quantum yield, and upper limit to production. Limnol. Oceanogr. 19:1-12.

Barbosa FAR, Tundisi JG, 1980. Primary production of phytoplankton and environmental characteristics of a shallow qua- ternary lake at Eastern Brazil. Arch. Hydrobiol. 90:139-161.

Benner R, 2002. Chemical composition and reactivity, p. 59-90. In: D.A. Hansell and C.A. Carlson (eds.), Biogeochemistry of marine dissolved organic matter. Academic Press.

Bertilsson S, Tranvik LJ, 1998. Photochemically produced carboxylic acids as substrates for freshwater bacterioplankton. Limnol. Oceanogr. 43:885-895.

Bertilsson S, Tranvik LJ, 2000. Photochemical transformation of dissolved organic matter in lakes. Limnol. Oceanogr. 45:753-762.

Bezerra-Neto JF, Pinto-Coelho RM, 2008. Morphometric study of Lake Dom Helvécio, Parque Estadual do Rio Doce (PERD), Minas Gerais, Brazil: a re-evaluation. Acta Limnol. Bras. 20:161-167.

Bittar TB, Vieira AAH, Stubbins A, Mopper K, 2015. Competition between photochemical and biological degradation of dissolved organic matter from the cyanobacteria Microcystis aeruginosa. Limnol. Oceanogr. 60:1172-1194.

Bracchini L, Dattilo AM, Hull V, Loiselle AS, Nannicini L, Picchi MP, Ricci M, Santinelli C, Seritti A, Tognazzia A, Rossia C, 2010. Spatial and seasonal changes in optical properties of autochthonous and allochthonous chromophoric dissolved organic matter in a stratified mountain lake. Photochem. Photobiol. Sci. 9:304-314.

Brighenti LS, Staehr PA, Gagliardi LM, Brandão LPM, Elias EC, Mello NAST, Barbosa FAR, Bezerra-Neto JF, 2015. Seasonal changes in metabolic rates of two tropical lakes in the Atlantic forest of Brazil. Ecosystems 18:589-604.

Catalán N, Obrador B, Felip M, Pretus JL, 2013. Higher reactivity of allochthonous vs. autochthonous DOC sources in a shallow lake. Aquat. Sci. 75: 581-593.

Champs JRB, 1992. [Algumas considerações sobre a situação sanitária da Bacia da Pampulha], p. 134-142. In: H. Godinho (ed.), [Anais do Seminário da Bacia Hidrográfica da Pampulha].[Book in Portuguese]. PBH, Belo Horizonte.

Christian D, Sheng YP, 2003. Relative influence of various water quality parameters on light attenuation in Indian River Lagoon. Estuar. Coast. Mar. Sci. 57:961-971.

Coble P, 2007. Marine optical biogeochemistry: The chemistry of ocean color. Chemical Reviews 107:402-418.

De Haan H, De Boer T, 1987. Applicability of light absorbance and fluorescence as measures of concentration and molecular size of dissolved organic carbon in humic Laken Tjeukemeer. Water Res. 21:731-734.

Fasching C, Battin TJ, 2012. Exposure of dissolved organic matter to UV-radiation increases bacterial growth efficiency in a clear-water Alpine stream and its adjacent groundwater. Aquat. Sci. 74:143-153.

Figueredo CC, Giani A, 2001. Seasonal variation in the diversity and species richness of phytoplankton in a tropical eutrophic reservoir. Hydrobiologia 445:165-174.

Gallegos CL, Moore K, 2000. Factors contributing to water-column light attenuation, p. 35-54. In: Chesapeake Bay submerged aquatic vegetation water quality and habitat-based requirements and restoration targets: a second technical synthesis. US Environmental Protection Agency, Annapolis.

Guillemette F, del Giorgio PA, 2012. Simultaneous consumption and production of fluorescent dissolved organic matter by lake bacterioplankton. Environ. Microbiol. 14:1432-1443.

Hanamachi Y, Hama T, Yanai T, 2008. Decomposition process 
of organic matter derived from freshwater phytoplankton. Limnology 9:57-69.

Helms JR, Stubbins A, Ritchie JD, Minor EC, Kieber DJ, Mopper K, 2008. Absorption spectral slopes and slope ratios as indicators of molecular weight, source and photobleaching of chromophoric dissolved organic matter. Limnol. Oceanogr. 53:955-969.

Henderson RK, Baker A, Parsons SA, Jefferson B, 2008. Characterization of algogenic organic matter extracted from cyanobacteria, green algae and diatoms. Water Res. 42: 3435-3445.

Henry R, Barbosa FAR, 1989. Thermal structure, heat content and stability of two lakes in The National Park of Rio Doce Valley (Minas Gerais, Brazil). Hydrobiologia 171:189-199.

Johannessen SC, Peña MA, Quenneville ML, 2007. Photochemical production of carbon dioxide during a coastal phytoplankton bloom. Estuar. Coast. Shelf Sci. 73:236-242.

Kahru M, Mitchell BG, 2001. Seasonal and nonseasonal variability of satellitederived chlorophyll and dissolved organic matter concentration in the California Current. J. Geophys. Res. 106:2517-2529.

Kieber RJ, Whitehead RF, Skrabal SA, 2006. Photochemical production of dissolved organic carbon from resuspended sediments. Limnol. Oceanogr. 51:2187-2195.

Kritzberg ES, Cole JJ, Pace ML, Granéli W, Bade DL, 2004. Autochthonous versus allochthonous carbon sources of bacteria: results from whole-lake $13 \mathrm{C}$ addition experiments. Limnol. Oceanogr. 49:588-596.

Loiselle SA, Bracchini L, Cózar A, Dattilo AM, Tognazzi A, Rossi C, 2009. Variability in photobleaching rates and their related impacts on optical conditions in subtropical lakes. J. Photochem. Photobiol. B 95:129-137.

Lønborg C, Álvarez-Salgado XA, Davidson K, Martínez-García S, Teira E, 2010. Assessing the microbial bioavailability and degradation rate constants of dissolved organic matter by fluorescence spectroscopy in the coastal upwelling system of the Ría de Vigo. Mar. Chem. 119:121-129.

Mackereth FJH, Heron J, Talling JF, 1978. Water analysis and some revised methods for limnologists. Freshwater Biological Association.

Maia-Barbosa PM, Barbosa LG, Brito SL, Garcia F, Barros CF, Souza MB, Mello N, Guimarães AS, Barbosa FA, 2010. Limnological changes in Dom Helvécio Lake (South-East Brazil): natural and anthropogenic causes. Braz J Biol. 70:795-802.

McKnight DM, Andrew ED, Aiken GR, Spaulding SA, 1994. Aquatic fulvic acids in algal rich Antarctic ponds. Limnol. Oceanogr. 39:1972-1979.

McMahon TG, Raine RCT, Fast T, Kies L, Patching JW, 1992. Phytoplankton biomass, light attenuation and mixing in the Shannon estuary, Ireland. J. Mar. Biol. Assoc. U K 72: 709-720.

Megard RO, Combs WS, Smith PD, Knoll AS, 1979. Attenuation of light and daily integral rates of photosynthesis attained by planktonic algae. Limnol. Oceanogr. 24:1038-1050.

Miller C, Gordon KG, Kieber RJ, Willey JD, Seaton PJ, 2009. Chemical characteristics of chromophoric dissolved organic matter in rainwater. Atmos. Environ. 43:2497-2502.

Moran MA, Sheldon WM, Zepp RG, 2000. Carbon loss and optical property changes during long-term photochemical and biological degradation of estuarine dissolved organic matter. Limnol. Oceanogr. 45:1254-1264.

Neale PJ, Helbling EW, Day TA, 2007. Symposium-in-print: UV Effects in aquatic and terrestrial environments: introduction. Photochem. Photobiol. 83:775-776.

Novais FL, 1992. [Ocupação urbana e erosão na bacia da Pampulha], p. 117-120.[Article in Portuguese]. In: Proc. Seminário da Bacia Hidrográfica da Pampulha. Anais, Belo Horizonte.

Obrador B, Pretus JL, 2008. Light regime and components of turbidity in a Mediterranean coastal lagoon. Estuar. Coast. Shelf. Sci. 77:123-133.

Obrador B, Pretus JL, 2013. Carbon and oxygen metabolism in a densely vegetated lagoon: implications of spatial heterogeneity. Limnetica 32:321-336.

Petrucio MM, Barbosa FAR, 2004. Diel variations of phytoplankton and bacterioplankton production rates in four tropical lakes in the middle Rio Doce basin (southeastern Brazil). Hydrobiologia 513:71-76.

Petrucio MM, Medeiros AO, Rosa CA, Barbosa FAR, 2005. Trophic state and microorganisms community of major subbasins of the middle Rio Doce Basin, southeast Brazil. Braz. Arch. Biol. Technol. 48:625-633.

Peuravouri J, Pihlaja K, 1997. Molecular size distribution and spectroscopic properties of aquatic humic substances. Anal. Chim. Acta 337:133-149.

Phlips EJ, Lynch TC, Badylak S, 1995. Chl a, tripton, color, and light availability in a shallow tropical inner-shelf lagoon, Florida Bay, USA. Mar. Ecol. Prog. Ser. 127:223-234.

Pinto-Coelho R, Bezerra-Neto JF, Giani A, Macedo CF, Figueiredo CC, Carvalho EA, 2003. The collapse of Daphnia laevis (Birge, 1878) population in Pampulha Reservoir, Brazil. Acta Limnol. Bras. 15:53-70.

Qualls RG, Richardson CJ, 2003. Factors controlling concentration, export, and decomposition of dissolved organic nutrients in the Everglades of Florida. Biogeochemistry 62:197-229.

Resck R, Bezerra-Neto JF, Pinto-Coelho RM, 2007. N[ova batimetria e uma avaliação ecológica de parâmetros morfométricos da Lagoa da Pampulha (Belo Horizonte, Brasil)].[Article in Portuguese]. Geografias 3:24-37.

Reynolds CS, 2009. Hydrodynamics and mixing in lakes, reservoirs, wetlands and rivers. In Biogeochemistry of inland waters: a derivative of encyclopedia of inland waters. Cary Institute of Ecosystem Studies Millbrook, NY, USA.

Rochelle-Newall EJ, Fisher TR, 2002. Chromophoric dissolved organic matter and dissolved organic carbon in Chesapeake Bay. Mar. Chem. 77:23-41.

Shank GC, Zepp RG, Vähätalo A, Lee R, Bartels E, 2010. Photobleaching kinetics of chromophoric dissolved organic matter derived from mangrove leaf litter and floating Sargassum colonies. Mar. Chem. 119:162-171.

Spencer RGM, Stubbins A, Hernes PJ, Baker A, Mopper K, Aufdenkampe AK, Dyda RY,2 Mwamba VL, Mangangu AM, Wabakanghanzi JN, Six J, 2009. Photochemical degradation of dissolved organic matter and dissolved lignin phenols from the Congo River. J. Geophys. Res.114:G03010.

Stedmon CA, Markager S, Tranvik L, Kronberg L, Slätis T, Martinsen W, 2007. Photochemical production of ammonium and transformation of dissolved organic matter in the Baltic Sea. Mar. Chem. 104:227-240. 
Tao S, 1998. Spatial and temporal variation in DOC in the Yichun River, China. Water Res. 32:2205-2210.

Teixeira MC, Azevedo JCR, Pagioro TA, 2011. Spatial and seasonal distribution of chromophoric dissolved organic matter in the Upper Paraná River floodplain environments (Brazil). Acta Limnol. Bras. 23:333-343.

Teixeira MC, Azevedo JCR, Pagioro TA, 2013. Photo-degradation effect on dissolved organic carbon availability to bacterioplankton in a lake in the upper Paraná river floodplain. Acta Sci. 35:47-54.

Thurman EM, 1985. Organic geochemistry of natural waters. Martinus Nijhoff / Dr. Junk, Dordrecht: 497 pp.

Tôrres IC, Araújo MAR, Pinto-Coelho RM, 1998. [Variação temporal de carbono pigmentado, carbono orgânico dissolvido e particulado na represa da Pampulha, Belo Horizonte/MG].[Article in Portuguese]. Ver. Brasil. Biol. 58:131-141.

Tranvik LJ, Wachenfeldt E von, 2009. Interactions of dissolved organic matter and humic substances, p. 464-470. In: G.E. Likens (ed.), Biogeochemistry of inland waters: a derivative of encyclopedia of inland waters. Academic Press.

Twardowski MS, Boss E, Sullivan JM, Donaghay PL, 2004. Modeling the spectral shape of absorbing chromophoric dissolved organic matter. Mar. Chem. 89:69-88.

Vähätalo AV, Salkinoja-Salonen M, Taalas P, Salonen K, 2000. Spectrum of the quantum yield for photochemical mineralization of dissolved organic carbon in a humic lake. Limnol. Oceanogr. 45:664-676.

Weishaar JL, Aiken GR, Bergamaschi BA, Fram MS, Fugii R, Mopper K, 2003. Evaluation of specific ultraviolet absorbance as an indicator of the chemical composition and reactivity of dissolved organic carbon. Environ. Sci. Technol. 37:4702-4708.

Wetzel RG, 1992. Gradient-dominated ecosystems - Sources and regulatory functions of dissolved organic-matter in fresh-water ecosystems. Hydrobiologia 229:181-198.

Yamaguchi H, Katahira R, Ichimi K, Tada K, 2013. Optically active components and light attenuation in an offshore station of Harima Sound, eastern Seto Inland Sea, Japan. Hydrobiologia 714:49-59.

Zhang Y, Liu X, Osburn CL, Wang M, Qin B, Zhou Y, 2013a. Photobleaching response of different sources of chromophoric dissolved organic matter exposed to natural solar radiation using absorption and excitation-emission matrix spectra. PLoS ONE 8:e77515.

Zhang Y, Liu X, Wang M, Qin B, 2013b. Compositional differences of chromophoric dissolved organic matter derived from phytoplankton and macrophytes. Org. Geochem. 55:26-37.

Zhang Y, Van Dijk MA, Liu M, Zhu G, Qin B, 2009. The contribution of phytoplankton degradation to chromophoric dissolved organic matter (CDOM) in eutrophic shallow lakes: field and experimental evidence. Water Res. 43:4685-4697.

Zhang Y, Yin Y, Liu X, Shi Z, Feng L, Liu M, Zhu G, Gong Z, Qin B, 2011a. Spatial-seasonal dynamics of chromophoric dissolved organic matter in Lake Taihu, a large eutrophic, shallow lake in China. Org. Geochem. 42:510-519.

Zhang Y, Yin Y, Zhang E, Zhu G, Liu M, Feng L, Qina B, Liu $\mathrm{X}, 2011 \mathrm{~b}$. Spectral attenuation of ultraviolet and visible radiation in lakes in the Yunnan Plateau, and the middle and lower reaches of the Yangtze River, China. Photochem Photobiol Sci. 10: 469-482.

Zhang YL, Zhang EL, Liu ML, Wang X, Qin BQ, 2007a. Variation of chromophoric dissolved organic matter and possible attenuation depth of ultraviolet radiation in Yunnan Plateau lakes. Limnology 8:311-319.

Zhang YL, Zhang B, Ma R, Feng S, Le C, 2007b. Optically active substances and their contributions to the underwater light climate in Lake Taihu, a large shallow lake in China. Fundam. Appl. Limnol. 170:11-19. 